\title{
Analysis of iron, calcium and zinc contents in formulated fish protein hydrolyzate (FPH) complementary feeding instant powder
}

\author{
${ }^{1}$ Putri, A.R., ${ }^{2}$ Anwar, A., ${ }^{3}$ Chasanah, E., ${ }^{3}$ Fawzya, Y.N., ${ }^{3}$ Martosuyono, P., ${ }^{1}$ Nuryanto and \\ $1, *$ Afifah, D.N. \\ ${ }^{I}$ Department of Nutrition, Faculty of Medicine, Diponegoro University, Semarang, Indonesia \\ ${ }^{2}$ Agroecotechnology Study Program, Faculty of Animal Husbandry and Agriculture, Diponegoro University, \\ Semarang, Indonesia \\ ${ }^{3}$ Center for Research on Product Processing and Biotechnology, Marine and Fisheries, Jakarta, Indonesia
}

\author{
Article history: \\ Received: 29 December 2019 \\ Received in revised form: 24 \\ February 2020 \\ Accepted: 29 February 2020 \\ Available Online: 30 May \\ 2020
}

\section{Keywords:}

Fish protein hydrolyzate (FPH),

Complementary feeding

Iron,

Calcium,

Zinc

DOI:

https://doi.org/10.26656/fr.2017.4(S3).S09

\begin{abstract}
Complementary feeding is a transition of the baby's intake over 6 months to meet the nutritional needs in addition to breast milk. Complementary feeding should contain complete nutritional components especially in minerals. Minerals are elements needed by the body for the overall body function. Children require calcium $(\mathrm{Ca})$, iron $(\mathrm{Fe})$, and zinc (Zn) for their body growth to prevent stunting. This study was aimed to analyse $\mathrm{Ca}, \mathrm{Fe}$ and $\mathrm{Zn}$ content in the formulated fish protein hydrolysate (FPH) complementary feeding porridge. A total of three formulations were produced namely F1, F2 and F3 and analysed for mineral content following AOAC method 999.11. From the analysis, F3 had the highest Fe content $(38.547 \mathrm{mg} / 100 \mathrm{~g})$ and $\mathrm{Zn}$ content $(5.751 \mathrm{mg} / 100 \mathrm{~g})$ while F1 had the highest $\mathrm{Ca}$ content $(65.152 \mathrm{mg} / 100 \mathrm{~g})$. Overall, F3 had the best mineral content to be formulated as a suitable FPH complementary feeding instant powder.
\end{abstract}

\section{Introduction}

The issue of nutrition is a major problem in Indonesia, which is included as one of the items in the Millennium Development Goals (MDGs) (UNICEF, 2009). Indonesia is trying to reduce the prevalence of malnutrition to reach $15.5 \%$ in 2015 . Children who are malnourished are more susceptible to disease, their growth and development are hampered, and their intelligence is decreasing. Therefore, the government through the Director-General of Community Health Development Ministry of Health seeks to overcome these problems, which can be done through the Food and Nutrition Alert System, Provision of Supplementary Food and Complementary Foods (Saputro and Hida, 2012).

Complementary feeding is recommended to start given when the baby is 6 months old because before that age the baby's body immunity against allergens is not optimal. One form of complementary feeding is an instant powder that is well known to the public and is widely circulating in the market. This complementary feeding instant powder is very practical compared to complementary feeding homemade. Making complementary feeding instant powder is very concerned about the completeness of nutrients that have been determined in the standard complementary feeding instant powder according to SNI-01-7111.1-2005. complementary feeding instant powder is generally made from a mixture of rice flour, skim milk, refined sugar, and vegetable oil. To be able to increase the nutritional content of complementary feeding instant powder, these ingredients can be substituted with other food ingredients. Terms of the complementary feeding instant powder nutrient content must include sufficient minerals (Ministry of Health Republic of Indonesia, 2002).

Minerals are elements needed by the human body that has an important role in maintaining body functions, both at the cellular, tissue, organ and overall body functions. The mineral content that must be present in complementary feeding instant powder according to SNI includes iron $(\mathrm{Fe})$, calcium $(\mathrm{Ca})$ and zinc $(\mathrm{Zn})$. Iron $(\mathrm{Fe})$ is one of the elements needed in the process of forming red blood cells. This red blood cell contains a chemical 
compound called hemoglobin, which functions to carry oxygen from the lungs and deliver it to all parts of the body (Kusudaryarti, 2013). Calcium (Ca) is the main constituent mineral that has an important role in the growth of children and $\mathrm{Zn}$ minerals needed by enzymes involved in metabolism in the body (Nasution, 2004).

Food sources that contain complete minerals can be obtained from animal or vegetable food sources. Vegetable food sources that can be made into complementary feeding formulas with complete mineral content can be obtained from green beans while animal food sources can be obtained from fish. In this study, making the complementary feeding formula using turmeric fish (Upeneus moluccensis). Turmeric fish was chosen because it is a type of fish that lives and eats on the seabed (demersal) which is large and easy to get at sea and has economic value (Novian, 2005).

Fish as a source of minerals after being processed in a certain way can be used as material enrichment for processed food/snacks, given the complete mineral content is useful for children's health and growth. Processing of fish into protein hydrolyzate aims to overcome fish damage and to get food that is more easily digested by the body. Currently, in Indonesia, there has not been much-developed processing of fish meat into fish protein concentrate. FPH has better functional properties than a fish meal because it has very high solubility and this solubility does not change much even though it gets high-temperature treatment for example in the sterilization process it can survive in liquid form at high concentrations. The process of making FPH uses a local microbial protease enzyme from Bacillus licheniformis which is processed with a long incubation period and a certain temperature so that it can produce FPH (Ariyani et al., 2012).

In this research, the processing of complementary feeding instant powder was processed by combining $\mathrm{FPH}$, green bean flour, skim milk, red bean flour, refined sugar and vegetable oil which had previously been through the optimization process using Response Surface Methodology (RSM) techniques to obtain the best formula. The choice of this form of instant powder is because the texture of the instant powder is the most appropriate food for children who are just getting complementary foods. Making an instant powder from FPH is expected to increase mineral content to meet the needs of undernourished children.

\section{Materials and methods}

\subsection{Complementary feeding preparation}

A total of three complementary feeding formulations (F1, F2, and F3) were used in this study obtained from the preliminary research using RSM methodology (Putri et al., 2019). The FPH complementary feeding instant powder was formulated following the composition in Table 1 and. All raw materials (brown rice flour, green beans flour, skim milk flour, FPH flour, and sugar) mixed using the drum dryer except for oil that added when the instant powder wants to be served (Putri et al., 2019)

Table 1. The composition of the complementary feeding formula

\begin{tabular}{ccccccc}
\hline & \multicolumn{7}{c}{ Composition $(\mathrm{g})$} \\
\cline { 2 - 7 } Formulas & $\begin{array}{c}\text { Brown } \\
\text { Rice }\end{array}$ & $\begin{array}{c}\text { Skim } \\
\text { Milk }\end{array}$ & FPH & $\begin{array}{c}\text { Green } \\
\text { Beans }\end{array}$ & Oil & Sugar \\
\hline F1 & 21.6 & 18 & 7.6 & 37.8 & 10 & 5 \\
F2 & 16.8 & 15 & 7.6 & 45.6 & 10 & 5 \\
F3 & 15.2 & 18 & 6.2 & 45.6 & 10 & 5 \\
\hline
\end{tabular}

\subsection{Mineral content analysis}

The determination of mineral content was carried out by the wet destruction method following AOAC method 999.11 (AOAC, 2002) perchloric acid (wet ashing). Sample of $1 \mathrm{~g}$ was dissolved in $15 \mathrm{~mL}$ deionized water. The dissolved sample was then added with $10 \mathrm{~mL}$ nitric acid $\left(\mathrm{HNO}_{3}\right)$ and $10 \mathrm{~mL}$ sulfuric acid $\left(\mathrm{H}_{2} \mathrm{SO}_{4}\right)$. The solution was heated on a hot plate until turned black indicating the organic material had oxidized. More $\mathrm{HNO}_{3}$ was added when the solution became yellowish until clear. Then, 2 drops of deionized water were added until no change in color. The sample was removed and cooled before transferring into a $50 \mathrm{~mL}$ measuring flask and topped up with deionized water. The absorbance of solution was measured using AAS (atomic absorption spectrophotometer) at $\lambda$ max for $\mathrm{Fe}=248.3 \mathrm{~nm} ; \mathrm{Ca}=$ $422.7 \mathrm{~nm}$; and $\mathrm{Zn}=213.9 \mathrm{~nm}$. The concentration of each was obtained from the regression equation of the calibration curve.

\section{Results and Discussion}

Mineral analysis in the complementary feeding formula shows the mineral content of iron, calcium, and zinc as shown in Figure 1.

\subsection{Iron $(\mathrm{Fe})$}

Iron is a nutrient that has a role in producing hemoglobin, an important component in red blood cells that is responsible for delivering oxygen throughout the body. In the process of growing children iron plays an important role in cell formation, including the formation of red blood cells. Thus, more optimal blood circulation. These red blood cells carry oxygen throughout the body, including the brain. Mineral analysis in the 


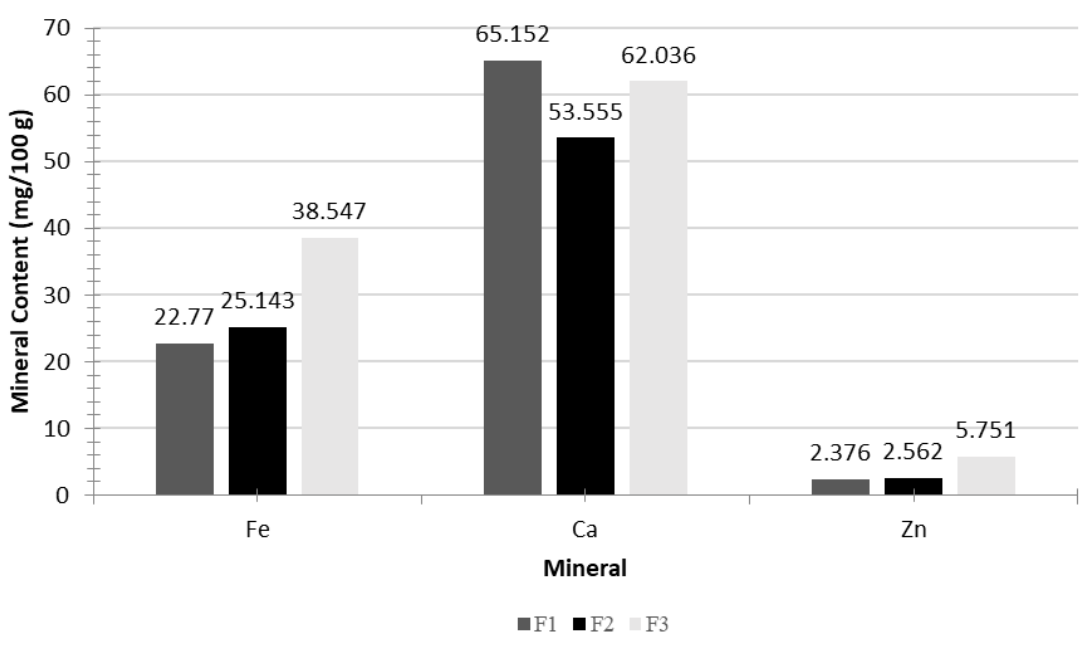

Figure 1. Mineral content in the complementary feeding formula

complementary feeding formula showed that the iron content in F1 was $22.77 \mathrm{mg} / 100 \mathrm{~g}$, F2 was 25.143 $\mathrm{mg} / 100 \mathrm{~g}$ and $\mathrm{F} 3$ was $38.547 \mathrm{mg} / 100 \mathrm{~g}$. In this case, it can be concluded that the highest iron content is F3 which is $38.547 \mathrm{mg} / 100 \mathrm{~g}$. This iron content is in accordance with the standards stipulated in the requirements of complementary feeding according to SNI 01-7111.1-2005 that the mineral content of iron that must be present in complementary feeding must be greater than $5 \mathrm{mg} / 100 \mathrm{~g}$ of material. The iron content in the formula can come from fish that have been hydrolyzed (0.21-1.58 mg/100 g), green beans (6.7 $\mathrm{mg} / 100 \mathrm{~g})$, and brown rice $(0.4 \mathrm{mg} / 100 \mathrm{~g})$. The high Fe content in the formula can be caused due to contamination from auxiliary equipment or water used in washing the equipment. Observation of the tools used such as a dryer (drum dryer) shows the presence of corrosion in some parts, especially the grinding part which is in direct contact with the formula. This rust is caused because the part is not coated by stainless steel. The possibility of contamination from water used to wash equipment is also another factor that should not be ignored (Nasution, 2004).

\subsection{Calcium (Ca)}

Calcium is a type of mineral that is very important for the growth and maintenance of teeth and bones. In addition, calcium is also needed by the nerves, heart and blood clotting system to function properly. In the process of growing children, calcium is a nutrient that is needed because it can increase bone density, optimize children's height, increase children's intelligence, enhance the immune system and maintain the stability of the body's metabolism (Hidayati et al., 2010).

Mineral analysis in the complementary feeding formula showed that the calcium content in F1 was $65.152 \mathrm{mg} / 100 \mathrm{~g}$, in F2 it was $53.555 \mathrm{mg} / 100 \mathrm{~g}$, and in F3 it was $62.036 \mathrm{mg} / 100 \mathrm{~g}$. In this case, it can be concluded that the formula which has the highest calcium content is F1 which is equal to 65.252 $\mathrm{mg} / 100 \mathrm{~g}$. The source of calcium in the formula comes from hydrolyzed fish $(94 \mathrm{mg} / 100 \mathrm{~g})$, green beans (132 $\mathrm{mg} / 100 \mathrm{~g}$ ), skim milk (123 mg/100 g), and brown rice $(10 \mathrm{mg} / 100 \mathrm{~g})$. This calcium content is still less than the standard requirements of complementary feeding according to SNI 01-7111.1-2005 which states that the ideal calcium content in complementary feeding is that it must be more than $200 \mathrm{mg} / 100 \mathrm{~g}$ of material. This can be an evaluation and input material and can be considered to provide calcium fortification or use fish bones as a source of calcium because it is known that fish bones have a high calcium content of $735 \mathrm{mg} / 100 \mathrm{~g}$ and can meet calcium requirements in the complementary feeding and meet the calcium needs of children (Nurkomala et al., 2018).

\subsection{Zinc (Zn)}

Zinc is one of the minerals needed by the body. This mineral has a variety of benefits, such as helping heal wounds, play a role in the sense of taste and smell, strengthen the immune system, help cell growth, and break down carbohydrates. Zinc is known to be beneficial for cell growth and maintaining the body's metabolism. Zinc deficiency will reduce the body's resistance to infection and child development (Nasution, 2004).

Mineral analysis in the complementary feeding formula showed that the zinc content in F1 was 2.376 $\mathrm{mg} / 100 \mathrm{~g}$, in F2 it was $2.562 \mathrm{mg} / 100 \mathrm{~g}$, and in F3 it was $5.751 \mathrm{mg} / 100 \mathrm{~g}$. In this case, it can be concluded that the formula which has the highest zinc content in F3 that is equal to $5.751 \mathrm{mg} / 100 \mathrm{~g}$. The zinc mineral content is in accordance with the standards stipulated in the complementary feeding requirements according to SNI 01-7111.1-2005 that the zinc mineral content required for complementary feeding must be greater than 2.5 
$\mathrm{mg} / 100 \mathrm{~g}$ of material (Ministry of Health Republic of Indonesia, 2002).

\section{Conclusion}

Complementary feeding instant powder formula contains mineral iron, calcium, and zinc. Where the highest iron content is in F3, which is $38.547 \mathrm{mg} / 100 \mathrm{~g}$. The highest calcium content is in F1 which is 65.152 $\mathrm{mg} / 100 \mathrm{~g}$ and the highest zinc content is in F3 which is $5.751 \mathrm{mg} / 100 \mathrm{~g}$. The mineral content of iron and zinc in the complementary feeding formula has met the standard requirements according to SNI 01-7111.4-2005 which requires that the complementary feeding must contain iron levels $\geq 5 \mathrm{mg}$ and zinc levels $\geq 2.5 \mathrm{mg}$. As for calcium content, the complementary feeding formula does not meet the SNI requirements which require a calcium content of $\geq 200 \mathrm{mg}$.

\section{Acknowledgment}

The author thanks to the National Innovation System Research Incentive (INSINAS) as a source of research funding.

\section{References}

Ariyani, N. (2012). Utilization of Turmeric Fish Bone Waste (Upeneus moluccensis) for Calcium Fortification (Ca) of Soymilk. Indonesia: IAIN Walisongo. BSc. Thesis.[In Bahasa Indonesia]

Association of Official Analytical Chemistry (AOAC). (2002). AOAC Official Method 999.11, Determination of Lead, Cadmium, Copper, Iron, and Zinc in Food, Atomic Absorption Spectrophotometry after Dry Ashing, 18th ed. USA: AOAC.

Hidayati, L., Hadi, H. and Kumara, A. (2010). Kekurangan Energi dan Zat Gizi Merupakan Faktor Risiko Kejadian Stunted pada Anak Usia 1-3 Tahun yang Tinggal di Wilayah Kumuh Perkotaan Surakarta. Jurnal Kesehatan, 3(1), 89-104. [In Bahasa Indonesia]

Kusudaryati, D.P.D. (2013). Kekurangan Asupan Besi dan Seng Sebagai Faktor Penyebab Stunting pada Anak. Profesi (Profesional Islam). Media Publikasi Penelitian, 10(1), 57-61. http://dx.doi.org/10.26576/ profesi.66 [In Bahasa Indonesia]

Ministry of Health Republic of Indonesia. (2002). Pedoman Umum Gizi Seimbang. Directorate General of Community Health Development. Jakarta, Indonesia: Ministry of Health Republic of Indonesia. [In Bahasa Indonesia]

Nasution, E. (2004). Efek suplementasi zinc dan besi pada pertumbuhan anak. Bagian Gizi Kesehatan
Masyarakat Fakultas Kesehatan Masyarakat Universitas Sumatera Utara. [In Bahasa Indonesia]

Novian, U. (2005). Karakteristik Miofibril Kering Ikan Kuniran (Upeneus sp) Diekstrak Menggunakan Enzim Papain dengan Metode Press Panas. Indonesia: Universitas Jember, BSc. Thesis. [In Bahasa Indonesia].

Nurkomala, S., Nuryanto, N. and Panunggal, B. (2018). Praktik Pemberian MPASI (Makanan Pendamping Air Susu Ibu) pada Anak Stunting dan Tidak Stunting Usia 6-24 Bulan. Indonesia: Universitas Diponegoro, BSc. Thesis. [In Bahasa Indonesia]

Putri, Y.I., Anwar, S., Afifah, D.N., Chasanah, E., Fawzya. and Yusro, N. (2019). Optimasi Formula MP-ASI Bubuk Sumber Protein dengan Substitusi Hidrolisat Protein Ikan dan Tepung Kacang Hijau Menggunakan Response Surface Methodology (RSM). Jurnal Aplikasi Teknologi Pangan, 8(4), 123 -129. https://doi.org/10.17728/jatp.4346 [In Bahasa Indonesia]

Saputro, W. and Hida, N.R. (2012). Faktor Demografi Risiko Gizi Buruk Dan Gizi Kurang. Makara, Kesehatan, 16(2), 95-101. [In Bahasa Indonesia]

Standar Nasional Indonesia (SNI) 01-7111.1-2005. (2005). Makanan pendamping air susu ibu (MP-ASI) -bagian 1: bubuk instan. Jakarta, Indonesia: Badan Standardisasi Nasional. [In Bahasa Indonesia]

UNICEF. (2009). Achieving MDGs through RPJMN. In Nutrition Workshop. Jakarta: Bappenas. 